Gut, 1967, 8, 32

\title{
Effect of decreased levels of endogenous gastric tissue histamine on acid secretion and stress ulcer formation in the rat
}

\author{
WALLACE P. RITCHIE, JR., JOHN J. BREEN, DAVID I. GRIGG, AND \\ OWEN H. WANGENSTEEN \\ From the Department of Surgery, University of Minnesota Medical School, \\ Minneapolis, Minnesota, U.S.A.
}

EDITORIAL COMMENT There is a substantial fall in the incidence of stress ulcers when the level of endogenous tissue histamine is reduced by inhibiting histidine decarboxylase activity.

The concept that endogenous tissue histamine may be the final common pathway in the production of gastric acid has recently been reviewed (Code, 1965). Kahlson, Rosengren, Svahn, and Thunberg (1964) have demonstrated that in the rat endogenous histamine from pre-formed mucosal stores is mobilized in response to both exogenous gastrin administration and refeeding. They also observed a concomitant increase in the mucosal histamineforming capacity, indicating that a feed-back mechanism exists whereby a decrease in the end product (histamine) results in an increase in activity of the enzyme responsible for maintaining mucosal histamine stores (histidine decarboxylase). Additional evidence that the action of exogenous stimulants of gastric acid secretion is mediated by the release and utilization of endogenous histamine is found in the work of Shore (1965), who noted in rats that the administration of insulin and reserpine caused a marked lowering of gastric histamine levels coincident with the production of gastric acid, and in the work of Levine (1965), and Haverback, Stubrin, and Dyce (1965), who reported similar findings using insulin, reserpine, gastrin, urecholine, and betazole hydrochloride (histalog). Amure and Ginsburg (1964) have also demonstrated that the administration of aminoguanidine, a compound which inhibits diamine oxidase activity and thus the degredation of histamine, potentiates the acid response of the rat gastric mucosa following gastrin administration.

In the rat, gastric mucosal histamine is produced through the process of intracellular decarboxylation

Supported by a U.S.P.H.S. grant, the John A. Hartford Foundation, and the Donald J. Cowling Fund for Surgical Research. of histidine by a substrate specific enzyme, histidine decarboxylase (Schayer, 1957). Studies in vivo and in vitro have established that pyridoxal phosphate is a necessary coenzyme for this reaction (Ono and Hagen, 1959) and that the carbonyl reagent semicarbazide is capable of inhibiting histidine decarboxylase activity in the guinea-pig kidney (Werle and Heitzer, 1938). Kahlson, Rosengren, and Thunberg (1963) have demonstrated that the amount of endogenous histamine in rat gastric mucosa is reduced significantly when the animal is maintained on a pyridoxine-deficient diet for two weeks. A further reduction occurs if semicarbazide is administered simultaneously in a daily dose of 100 $\mathrm{mg} . / \mathrm{kg}$.

The relationship between acid production and peptic ulcer is well known. The studies cited above suggest the intriguing possibility that by decreasing the level of endogenous tissue histamine one might effect a reduction in the production of gastric acid and, in turn, decrease ulcerogenesis. Numerous studies indicate that ulcerations in the glandular portion of the stomach can be expected in $80 \%-90 \%$ of rats subjected to stress induced by restraint. While this preparation is certainly not associated with the hypersecretion of acid (Bonfils, Rossi, and Lambling, 1958; Menguy, 1960), it may nevertheless be properly classified as 'peptic' in that the presence of acid, and pepsin appears to be a necessary concomitant to the development of ulcers under these conditions (Brodie and Hanson, 1960; Hanson and Brodie, 1960; McFee, Stone, Goodale, Bernstein, and Wangensteen, 1963).

This study was undertaken, therefore, to determine 
if decreased levels of gastric tissue histamine in the rat were associated with alterations in gastric acid production and in the incidence of restraint-induced gastric ulcer.

\section{METHODS AND MATERIALS}

Two groups of 29 adult female rats of the SpraqueDawley strain were studied. The rats were identically housed, three rats to a cage, in a controlled humidity, constant temperature $\left(29^{\circ} \mathrm{C}\right.$.) environment. Group A was maintained on a pyridoxine-deficient diet for 14 days. Group B was maintained on a similar diet to which adequate amounts of pyridoxine were added. The rats in group A received subcutaneous injections of semicarbazide $(50 \mathrm{mg} . / \mathrm{kg}$.) twice daily during the three final days of the experiment. The rats in group B were administered an equivalent volume of normal saline during this period. The amount of food ingested daily by each group was approximately the same and no significant differences in body weight or appearance were detectable at the conclusion of the experiment.

After the fourteenth day of treatment five rats in each group were fasted for 12 hours and decapitated. The stomachs were then rapidly excised for histamine assay. This was accomplished by carefully dissecting the glandular mucosa free from the underlying submucosal and muscular layers. The individual mucosal specimens were pooled and homogenized in 9 volumes of 0.4 normal perchloric acid. The histamine content of the pooled sample was then assayed by the fluorometric method of Shore, Burkhalter, and Cohn (1959). Results are expressed as micrograms per gram of wet tissue. In this laboratory the standard deviation of the technique determined by assaying in replicate fashion a large number of samples is $\pm 3.09 \mu \mathrm{g}$. $/ \mathrm{g}$.

An additional nine rats in each group were fasted for 24 hours and, under light ether anaesthesia, subjected to four-hour pyloric ligature by the method of Shay. Following decapitation, the gastric contents of each rat were individually assayed for volume of secretion, free acid production by titration to $p \mathrm{H} 3.5$ with $0.01 \mathrm{~N}$ sodium hydroxide using Toepfer's reagent as an indicator, and total acid production by titration to $p \mathrm{H} 8$ with $0.01 \mathrm{~N}$ sodium hydroxide using phenolphthalein indicator. The remaining 15 rats in each group were immobilized for 16 hours in individual wire mesh restraint cages having an average volume of $600 \mathrm{ml}$. All the animals were fasted during this period but water was allowed ad libitum. Following decapitation, their stomachs were removed and quantitated for the number, size, and location of ulcers by two independent observers unaware of the treatment received by each group.

\section{RESULTS}

The results of this study are summarized in Table I. The tissue histamine content of the five rat stomachs from group B was $21.0 \mu \mathrm{g}$./g. In contrast, the amount of histamine present in the stomachs of five rats from group A was reduced to $6 \cdot 3 \mu \mathrm{g}$./g. Secretory volume and free and total acid production in response to a standard stimulus were also markedly reduced in group $\mathrm{A}$, and these alterations, when compared with control values, were statistically significant to the $\mathbf{0 . 0 5}$ level of biological confidence. Following 16 hours of restraint, punctate ulcerations of the glandular mucosa were evident in 12 of 15 rats $(80 \%)$ in group B. The average longest diameter of these ulcers was $1.5 \mathrm{~mm}$. In contrast, glandular ulcerations were noted in only three rats $(20 \%)$ in group $A$, their average longest diameter being $0.5 \mathrm{~mm}$. The total number of ulcers in group B was 19; in group A, seven. No qualitative differences were noted microscopically between the ulcers developed in each group.

\section{DISCUSSION}

This study confirms the findings of Kahlson et al. (1963) that inhibition of histidine decarboxylase activity results in decreased levels of endogenous gastric tissue histamine in the rat. In addition, it is evident that a substantial concomitant reduction in both the incidence and severity of stress ulcers induced by restraint is noted under these circumstances. The manner in which this is accomplished is not clear, primarily because the precise mechanisms involved in the pathogenesis of stress ulcer remain to be elucidated. However, in view of the

TABLE I

EFFECT OF DECREASED LEVELS OF ENDOGENOUS GASTRIC TISSUE HISTAMINE ON ACID SECRETION AND STRESS ULCER FORMATION IN THE RAT

Gastric Acid Secretion (Four-Hr. Pyloric Ligation)

-

Tissue Histamine ( $\mu \mathrm{g} . / \mathrm{g}$.

$\begin{array}{cc}\text { Vol. }(\mathrm{ml} .) \\ \text { Group } \mathrm{A}^{2} & 2 \cdot 0( \pm 1 \cdot 17)\end{array}$

(9 rats)

Group B $5 \cdot 8( \pm 2 \cdot 10)$

(9 rats) $\mathrm{p}<\cdot 01 \quad \mathrm{p}<\cdot 01$

Free Acid (mEq.)

Total Acid (mEq.)

Stress Ulcer Formation

(5 rats)

Group Bs $21 \cdot 0( \pm 3 \cdot 39)$

(5 rats)

$0 \cdot 10( \pm 0 \cdot 12)$
$0.38( \pm 0 \cdot 10)$
p $<.01$
each group.

$0 \cdot 19( \pm 0 \cdot 15)$

$0.57( \pm 0 \cdot 14)$

$\mathrm{p}<\cdot 01$

\begin{tabular}{lccc}
\hline & $\begin{array}{l}\text { No. Rats } \\
\text { with Ulcer }\end{array}$ & $\begin{array}{l}\text { Total No. } \\
\text { Ulcers }\end{array}$ & $\begin{array}{l}\text { Average Ulcer } \\
\text { Diameter }(\mathrm{mm} .)\end{array}$ \\
\hline $\begin{array}{l}\text { Group A } \\
\text { (15 rats) }\end{array}$ & $3(20 \%)$ & 7 & 0.5 \\
$\begin{array}{l}\text { Group B } \\
\text { (16 rats) }\end{array}$ & $12(80 \%)$ & 19 & 1.5
\end{tabular}

${ }^{1}$ Bracketed figures indicate values of standard deviation for each group.
${ }^{2}$ Pyridoxine-deficient diet for 14 days. Semicarbazide, $100 \mu \mathrm{g}$. $/ \mathrm{kg}$. for three days.

${ }^{3}$ Vitamin B complete diet for 14 days. Equivalent volumes of saline for three days. 


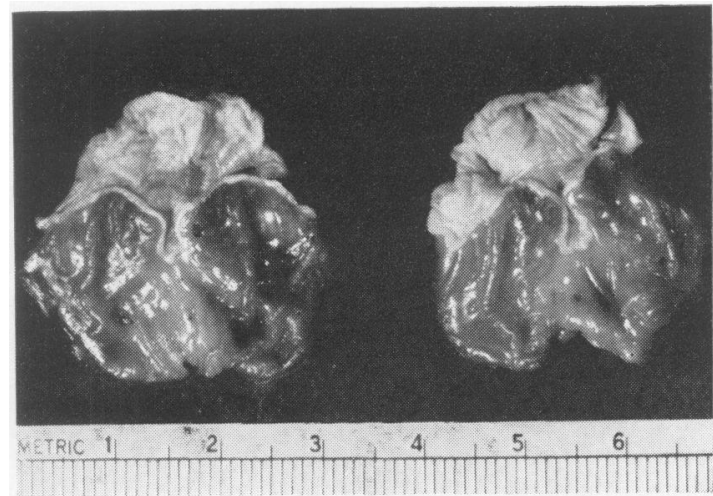

FIG. 1. (Left) Control stomach following 16 hours of stress. (Right) Histamine-deficient stomach following 16 hours of stress.

marked decrease in secretory volume and acid production noted in the rats with low levels of tissue histamine, the role of acid peptic digestion must be considered. Bonfils et al. (1958), using rats provided with transduodenal gastric fistulae, noted no difference in gastric acid production between animals subjected to six hours of restraint and comparable controls. In a similar study, Menguy (1960) subjected rats to a four-hour period of stress following pyloric ligature and found an actual reduction in gastric acid production in these animals when compared to comparable but unstressed controls. It would appear, then, that restraintinduced ulcer is not accompanied by a concomitant increase in acid production. On the other hand, Menguy (1960) and Brodie and Hanson (1960) both remarked on the protective effect afforded in this preparation by prior ablation of the vagus nerves. In parallel studies, Hanson and Brodie (1960) demonstrated a significant reduction in both acid secretion and ulcer formation when cholinergic blocking agents were administered simultaneously. Additionally, McFee and his associates (1963) noted that the incidence of stress ulcer formation in response to starvation and cold was reduced from $92.5 \%$ to $33.3 \%$ following an episode of gastric freezing, a procedure which has been demonstrated to alter markedly the ability of the intact rat's stomach to secrete acid (Ritchie, Breen, and Wangensteen, 1966). These studies provide some evidence, albeit indirect, that acid peptic digestion probably plays at least a permissive role in the development of stress ulcer. Decreased levels of endogenous histamine, then, might be expected to exert a protective effect under these circumstances by reducing the amount of gastric acid produced.

The decrease in acid secretion in the histamine- deficient, pylorus-ligated rat demonstrated in this study is in accord with the findings of Levine (1965) and Thayer, Toffler, Chapo, and Spiro (1965), but not with those of Kahlson et al. (1963) who demonstrated that even under conditions of histamine deprivation the secretory response to gastrin was normal. The reasons for the conflict in these data are obscure, particularly in view of the fact that the average mucosal histamine content in Kahlson's series $(7 \cdot 4 \mu \mathrm{g}$./g.) was comparable to our own $(6 \cdot 3$ $\mu \mathrm{g} . / \mathrm{g}$.). It may be that differences in the magnitude of the stimulus employed to induce secretion are responsible, Kahlson administering gastrin in near maximal doses likely to be capable of inducing additional acid secretion in pylorus-ligated rats.

A second explanation for the observed protective effect afforded by decreased gastric tissue histamine content is suggested by the work of Franco-Browder, Masson, and Corcoran (1959), who observed focal vascular changes leading to the development of acute ulcerations in the glandular mucosa of the rat following administration of polymyxin $\mathrm{B}$, a potent histamine liberator. No significant protection was provided under these circumstances by the intragastric administration of antacids whereas complete protection was afforded by the simultaneous administration of antihistaminics. It has been suggested, on the basis of this work, that ulcerations noted following the release of endogenous histamine are a result of vascular rather than acid peptic factors (Watt, 1963). If such a mechanism is operative in the production of stress ulcer, then decreased mucosal histamine stores might vitiate against these changes in the microcirculation, thus reducing the incidence of ulcer formation. The applicability of this concept to restraint-induced ulcer must await the demonstration that endogenous histamine is indeed liberated in large amounts from the glandular mucosa of the rat under stress. In this regard, it is of interest that Guth and Hall (1966) have recently demonstrated a decrease in gastric mucosal mast cell content associated with engorgement of the gastric microcirculation under conditions of restraint.

\section{SUMMARY AND CONCLUSIONS}

The level of endogenous gastric tissue histamine was found to be markedly decreased relative to control levels in rats which were maintained on a pyridoxine-deficient diet for two weeks and which received semicarbazide, $100 \mathrm{mg} . / \mathrm{kg}$., during the final three days of this period.

The volume of gastric secretion and free and total production of acid in response to pyloric 
ligation were also significantly reduced under conditions of histamine deficiency.

Decreased levels of tissue histamine were found to afford significant protection against the development of restraint-induced ulceration in the glandular portion of the rat's stomach.

In our opinion, the most likely explanation for the decreased incidence of stress ulcer lies in the impaired ability of the treated rats to produce gastric acid.

\section{REFERENCES}

Amure, B. O., and Ginsburg, M. (1964). Inhibitors of histamine catabolism and the action of gastrin in the rat. Brit. J. Pharmacol., 23, 476-485.

Bonfils, S., Rossi, G., and Lambling, A. (1958). Étude de la sécrétion gastrique du rat par fistule duodénale. Rev. frans. Étud. clin. biol., 3, 977-981.

Brodie, D. A., and Hanson, H. M. (1960). A study of the factors involved in the production of gastric ulcers by the restraint technique. Gastroenterology, 38, 353-360.

Code, C. F. (1965). Histamine and gastric secretion: A later look. 1955-1965. Fed. Proc., 24, 1311-1321.

Franco-Browder, S., Masson, G. M. C., and Corcoran, A. C. (1959). Induction of acute gastric lesions by histamine liberation in rats. J. Allergy, 30, 1-10.

Guth, P. H., and Hall, P. (1966). Microcirculatory and mast cell changes in restraint-induced gastric ulcer. Gastroenterology, 50, 562-570.

Hanson, H. M., and Brodie, D. A. (1960). Use of the restrained rat technique for study of the antiulcer effect of drugs. J. appl. Physiol., 15, 291-294.
Haverback, B. J., Stubrin, M. I., and Dyce, B. J. (1965). Relation of histamine to gastrin and other secretagogues. Fed. Proc., 24, 1326-1330.

Kahlson, G., Rosengren, E., Svahn, D., and Thunberg, R. (1964). Mobilization and formation of histamine in the gastric mucosa as related to acid secretion. J. Physiol. (Lond.), 174, $400-416$.

- Rosengren, E., and Thunberg, R. (1963). Observations on the inhibition of histamine formation. Ibid., 169, 467-486.

Levine, R. J. (1965). Effect of histidine decarboxylase inhibition on gastric acid secretion in the rat. Fed. Proc., 24, 1331-1333.

McFee, A. S., Stone, N. H., Goodale, R. L. Jr., Bernstein, E. F., and Wangensteen, O. H. (1963). Prevention of stress-induced ulce in the rat by gastric freezing. J. Amer. med. Ass., 186, 917-919.

Menguy, R. (1960). Effects of restraint stress on gastric secretion in the rat. Amer. J. dig. Dis., 5, 911-916.

Ono, S., and Hagen, P. (1959). Pyridoxal phosphate: a coenzyme for histidine decarboxylase. Nature (Lond.), 184, 1143-1144.

Ritchie, W. P. Jr., Breen, J., and Wangensteen, O. H. (1966). Freezing of the intact rat stomach: an indication of the biological potential of the technique. Fed. Proc. (abstr.), 25, 513.

Schayer, R. W. (1957). Histidine decarboxylase of rat stomach and other mammalian tissues. Amer. J. Physiol., 189, 533-536.

Shore, P. A. (1965). Release of histamine from stomach by vagusstimulating drugs: Association with gastric acid secretion. Fed. Proc., 24, 1322-1325.

—, Burkhalter, A., and Cohn, V. H., Jr. (1959). A method for the fluorometric assay of histamine in tissues. J. Pharm. exp. Ther., 127, $182-186$.

Thayer, W. R., Toffler, A. H., Chapo, G., and Spiro, H. M. (1965) Inhibition of restraint ulcers in the rat by pyridoxine deficiency. Yale J. Biol. Med., 38, 257-264.

Watt, J. (1963). Experimental histamine ulceration. In Pathophysiology of Peptic Ulcer, Edited by S. C. Skoryna. Lippencott, Philadelphia.

Werle, E., and Heitzer, K. (1938). Zür Kenntnis der Histidindecarboxylase. Biochem. Z., 299, 420-436. 